\title{
Application of Transaction Cost Theory on Repurchase Intention
}

\author{
Li-Shan Chen, Associate Professor \\ School of Management, Fujian University of Technology \\ Fuzhou City, Fujian, China. \\ sun56@ms8.hinet.net
}

\begin{abstract}
This study presents a theoretical model for understanding repurchase intention for customers. An empirical study was conducted to examine the model. The results indicate that customers' intention to repurchase online is negatively associated with their perceived transaction cost, and perceived transaction cost is associated with resources of ethnic, personal, and indirect quanxi. Furthermore, impulse buying, and environment will influence repurchase intention when customers consider online shopping. According to the results of empirical study, implications and suggestion for future research are discussed.
\end{abstract}

Keywords-Transaction Cost Theory, Repurchase, Impulse Buying, Quanxi, Ethnic Resource Introduction

\section{INTRODUCTION}

With the improvement of the technology, the proportion of using internet has increased rapidly worldwide. According to Taiwan Network Information Center (TWNIC), the number of Internet users is up to 16 million and the proportion of internet usage is $77.66 \%$ during the year of 2015 in Taiwan. In addition, mobile internet usage and wireless internet usage have increased from $25.91 \%$ in 2012 to $47.27 \%$ in 2015 . Among all the activities those Internet users have used, the major activities are using social networking site, instant messenger, visiting webpages and online shopping.

In the past, buying the products in virtual stores or shopping malls was the mainstream. However, with the growth and rising of popularity of Internet, it has dramatically influence on business and the way consumers purchase products or services. Currently, there are firms utilize the benefit of Internet to extent their business increasingly. The relatively low costs related to selling product or services on the internet make it profitable and more effective for sellers. Online sellers reduce the costs including maintaining the products in store and rent cost for expensive urban or suburban real estate and costs on in-store salespeople. As a result, many retailers and store owners start to sell service or products online. Internet attracts consumers to purchase online instead of shopping in store because internet makes it flexible for people to search information across countries to countries whenever they are willing to do. It turns out that customers search for products, compare to the quality in different online stores, order and pay for the items all through the Internet.

\section{THEORETICAL BACKGROUND}

\section{A. Transaction Cost Theory}

The theory of transaction cost was first introduced by Coase (1937) in his article "The nature of Firm", he was in an attempt to explain why firms exist. Coase defined that transaction cost is costs when making exchange in the market which includes adapting, negotiating, contracting and monitoring.

In classic Economic Theory, it was considered that all production could be carried on by a large firm and information is symmetric in the market. Thus, firms and the market could trade without cost. However, Coase mentioned information is not always symmetric in the real market.

Moreover, contracts in an uncertain environment sometimes are incomplete and have to be frequently renegotiated. The costs of haggling about division of surplus may be considerable, particularly if there is asymmetric information and asset specificity

Williamson [1] further mentioned transaction cost incurred due to incomplete contracting. Therefore, Williamson [2] divided transaction cost into ex ante and ex post. Ex ante transaction cost includes information searching cost, negotiating and contracting cost. On the other side, ex post transaction cost includes monitoring the process of transaction and enforcing the contract.

\section{B. Ethnic resource and Personal resource}

Light"s [3] study indicated ethnic resources as the major factor increasing the entrepreneurial performance of the ethnic community. Some scholars argued that there is distinction between ethnic and personal sources. [4,5], therefore, both ethnic and personal resources are used to improve performance.

Personal resources refer to individuals ${ }^{\text {ee }}$ ability to control and impact on their environment successfully[6]. Yang et al. [7] defined personal resource as education, English fluency, dependence on personal saving for capitalization, and premigration business experience on explaining Chinese immigrant business. In this study, personal resources include 
individual purchase experience in the past.

\section{Indirect Quanxi}

In order to understand network resources of online consumers in Taiwan, it is important to understand quanxi, as it is fundamental to Chinese business[8]).In Taiwan, interpersonal connection called quanxi. Yang [9] defined quanxi as a relationship between objects, forces, or persons. Not only can be used to describe the relationship between friendship, kinship and husband-wife, it can also be used to describe social connection based on mutual interest and benefit. Once there is a guanxi relationship between two people, one can ask a favor of the other with expectation that the "favor" will be returned in any kinds of forms in the future. Other scholar defined guanxi is a system of personal connections that carry-term social obligations and guanxi plays a significant role in relationships within and between Chinese businesses [10,11]

\section{Impulse Buying}

The impulse to buy may be emotionally and stimulate a consumeres action. Impulse buying occurs when a consumer experiences an instant, power and persistent urge to buy something immediately. Moreover, consumers sometimes feel temporary out of control and results in diminished regard for its consequences[12]. Stern[13a,b] defined buying as planned, unplanned, or impulsive. A planned act refers to spend time on searching and gradually lead to decision-making. Oppositely, unplanned buying including impulsive buying refers to limited information search and plans before making decision. In previous studies, most scholars agreed that consumers feel an instant satisfaction when consumers impulsive purchase goods. $[14,15]$. Some even indicated impulse buying has more influence than planned purchasing[16].

\section{E. Environment}

Titus and Everett [17] stated that shopping environment is an important element in the consumer retail search process. Ward et al. [18] suggested two factors of physical environment that influence potential consumer ${ }^{\text {ee }}$ s intention: (1) the external environment includes visible prior to entry into the retail store or service area (i.e. parking lot, entrance). (2). the internal environment includes the visible part from the inside of the retail stores. Several studies have showed environment has positively related to consumers ${ }^{\text {ee }}$ behavior. $[19,20]$.

In short, the environment of a store should be attractive enough for a consumer to enter and the inside of a store should be acceptable and sufficient for a consumer. [21]. In this study, environment is defined as external and internal environment. External environment refers to accessibility of internet includes online stabilization. In contrast, internal environment refers service and quality refers to consumers ${ }^{\text {ee }}$ evaluations about the overall environment of the online stores.

\section{RESEARCH MODEL AND HYPOTHESES}

\section{A. Research Model}

Following the theoretical background, this study conceptualize a theoretical research model by transaction cost theory. Research model was shown as Figure 1.

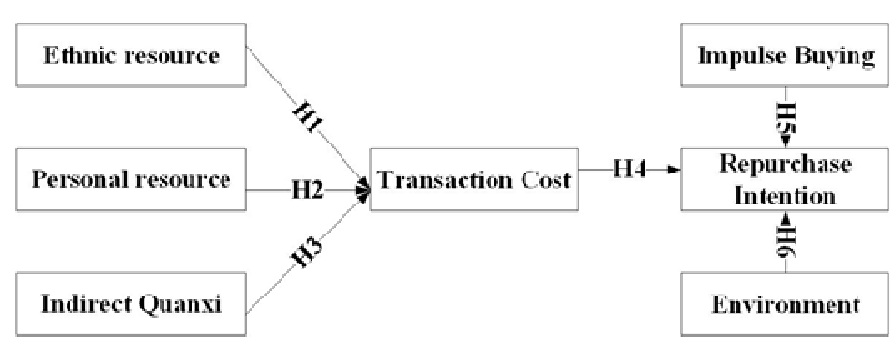

FiguRE 1. RESEARCH MODEL

\section{B. Research Hypotheses}

According to the study of Yang et al. [7], the integrative framework proposed that Ethnic/Personal resources, Strong/Weak ties, and Direct/Indirect quanxi were adopted to investigate influence on transaction costs. In the study of Yang et al. [7] indicated resource-based has negatively influence transaction costs. Hence, the following hypothesis is:

\section{H1: Ethnic resource is negatively related to transaction cost.}

As mentioned previously, personal resources refer to individuals ${ }^{e e}$ ability to adjust and control their environment successfully [6]. Personal resource is used in broadly fields. Eisenhardt and Schoonhoven adapted resources to view entrepreneurial firms. In Sequeira and Rasheed finding, personal resource plays a major role when start a business. Hence, the hypothesis is proposed as following:

$\mathrm{H} 2$ : Personal resource is negatively related to negotiation transaction costs

In Chinese communities, interactions with one another are considered as part of a whole relationship [7]. In that guanxi can reduce the risk of online transactions. Referring to indirect quanxi in online shopping, consumers can use indirect quanxi include neighbors and workplace ties to reduce transaction cost. Thus, hypotheses are developed as follows:

H3: Indirect quanxi is negatively related transaction cost.

From the perspective of Transaction Cost Theory, the concept of transaction costs is crucial for consumers ${ }^{\text {ee }}$ buying decision both in traditional stores and online stores. If the two parties distrust or had a strong suspicion on each other will increase transaction costs, and high transaction costs would make the transaction inefficient, resulting in the intention on transaction will reduce and even cancel the transaction.. Hence, the following hypotheses are: 
H4: Transaction cost is negatively related to repurchase intention.

H5: Impulse buying is positively related to the repurchase intention.

H6: Environment is positively related to repurchase intention.

\section{RESEARCH DESIGN AND METHODOLOGY}

The researcher converts each constructs into a questionnaire in order to collect the quantitative data. Survey designed was as online questionnaire because of less cost and less time for effective administration, larger sample sizes and higher response rate.

In this study, hypotheses and measurement items of each construct in the proposed research model were developed and conducted based on the existing studies. All the items were measured using a five-point Likert Scale with ranging from strongly disagree (1) to strongly agree (5) for measuring the items of construct. (i.e. 1 = strongly disagree, 2 = disagree, $3=$ neither disagree nor agree, $4=$ agree, and $5=$ strongly agree).

This study used Partial Least Squares (PLS) to analyze the data because PLS is a component-based Structural Equation Model technique used in evaluating the path coefficient of the model. In addition, it combines the uses of factor analysis for measuring parameters and model structures as well as multiple linear regressions. The two-step approach was used to analyze the data of this study. First step regarded to analyze the measurement model. The advantage is that it can place minimum restrictions on sample size, measurement scales and residual distributions.

\section{RESULT}

Research result was shown as Figure 2.

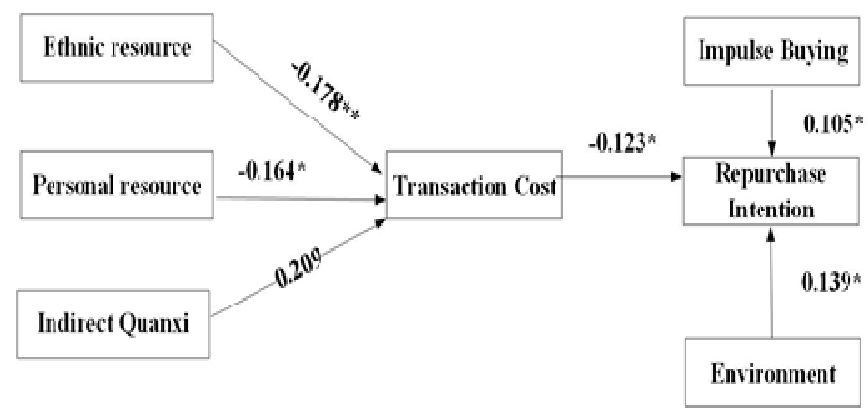

FIGURE 2. RESEARCH RESULT

\section{CONCLUSION}

In this study, several findings based on previous theories proposed by practitioners and researchers are conducted. First, ethnic resource negatively influences search cost. Consumers who join shopping group to gain ethnic can reduce the time and efforts on searching for products or services. Personal resource negatively associates with comparing prices and making agreement with online retailers when consumers get involved in online shopping.

Impulse buying is positively related to consumers ${ }^{\text {ee }}$ online purchase intention. Impulse buy occurs when consumers feel an instant desire to purchase, those consumers who perceive an urgent to have the products or services are likely to purchase online which is consistent with the argument proposed by Zhang et al. and Liao

\section{References}

[1] O.E. Williamson. "Transaction-cost economics: the governance of contractual relations," Journal of law and economics, 1979, pp.233-261.

[2] O. E. Williamson. "The economic institutions of capitalism" Simon and Schuster, 1985.

[3] M. G. Martinsons. "Relationship-Based E-Commerce: Theory and Evidence from China," Information Systems Journal, 18(4), 2008, pp. 331-356.

[4] M. Yinger. "Ethnicity," Annual Review of Sociology, 11, 1985, pp.151-180

[5] M. Fishbein, and I. Ajzen, I. "Belief, Attitude, Intention, and Behavior: An introduction to theory and research,” Reading, MA: Addison-Wesley.2015.

[6] S. E. Hobfoll, R. J. Johnson, N. Ennis, and A.P. Jackson.

"Resource loss, resource gain, and emotional outcomes among inner city women," Journal of Personality and Social Psychology, 84, 2013, pp632-643

[7] X. Yang, E. Y. H. Ho, and A. Chang. "Integrating the resource-based view and transaction cost economics in immigrant business performance," Asia Pacific Journal of Management, 29(3), 2012, pp753-772.

[8] I. H. Light. "Ethnic enterprise in America: Business and welfare among Chinese, Japanese, and Blacks," Univ of California Press.1972.

[9] M. M.Yang. "Gifts, favors and banquets: The art of social relationships in China. Ithaca," NY: Cornell University Press.1994.

[10] Z. X. Chen, and A. M. Francesco. "Employee demography, organizational commitment, and turnover intentions in China: do cultural differences matter?" Human relations, 53(6), 2000, pp869-887.

[11] S. H. Park, and Y. Luo. "Guanxi and organizational dynamics: Organizational networking in Chinese firms," Strategic management journal,22(5), 2001, pp455-477.

[12] D. W. Rook. "The buying impulse," Journal of consumer research, 1987, pp189-199.

[13a] H. Stern. "The significance of impulse buying today," Journal of Marketing, 26(2), 1962, pp59-63.

[13b] H. Stern "The significance of impulse buying today," The Journal of Marketing, 1962, pp59-62.

[14] D.W. Rook, and R.J. Fisher. "Trait and normative aspects of impulsive," 1995.

[15] A. Hausman. "A multi-method investigation of 
consumer motivations in impulse buying behavior," Journal of Consumer Marketing, 17(5), 2015, pp403419.

[16] J. A. Lee, and J. J. Kacen. "Cultural influences on consumer satisfaction with impulse and planned purchase decisions," Journal of Business Research,61(3), 2016, pp265-272.

[17] P. A. Titus, and P. B. Everett. "The consumer retail search process: a conceptual model and research agenda," Journal of the Academy of Marketing Science,23(2), 1995, pp106-119

[18] J. C. Ward, M. J. Bitner, and J. Barnes. "Measuring the prototypically and meaning of retail environments," Journal of Retailing, 68(2), 1992, pp194

[19] M. P. Gardner, and G. J. Siomkos. "Toward a methodology for assessing effects of in-store atmospherics," Advances in consumer research, 13(1), 1986, pp 27-31.

[20] B. Loken, and J. Ward. "Alternative approaches to understanding the determinants of typicality," Journal of Consumer Research, 1990, pp111-126.

[21] V. Kumar, and K. Karande. "The effect of retail store environment on retailer performance," Journal of Business Research, 49(2), 2000, pp167-181. 